\title{
Jurist-Diction
}

Volume 4 No. 1, Januari 2021

\section{Jaminan Hak Asasi Manusia Narapidana Dalam Pembinaan Narapidana di Lembaga Pemasyarakatan}

\author{
Fajar Putra Prastina R. \\ fajar.putra.prastina-2014@fh.unair.ac.id \\ Universitas Airlangga
}

How to cite:

Fajar Putra Prastina R.,

'Jaminan Hak Asasi Manusia

Narapidana Dalam Pembinaan

Narapidana Di Lembaga

Pemasyarakatan' (2021) Vol. 4

No. 1 Jurist-Diction.

Histori artikel:

Submit 09 November 2020;

Diterima 03 Desember 2020

Diterbitkan 5 Januari 2021.

DOI:

10.20473/jd.v4i1.24295

p-ISSN: 2721-8392

e-ISSN: $2655-8297$

\section{Abstract}

The rights of assisted citizens as Indonesian citizens who lost their independence due to criminal acts must be carried out in accordance with human rights. In practice, many rights of prisoners in prison have not been fulfilled. Whether the provisions of the statutory regulations are in accordance with the guarantee of human rights, whether the implementation of the development of prisoners in prisons is in accordance with the laws and regulations. This research method uses empirical and normative legal research types. The conclusion of this research is the regulation of the correctional system as part of an integrated criminal ju8stice system is sufficient to regulate the development of prisoners in prisons with the perspective of respecting the human rights of prisoners. The implementation of the human rights of prisoners in the development of prison inmates guaranteed by law has not been fully fulfilled by the government, in this case the Director General of Corrections, Ministry of Law and Human Rights.

Keywords: Prisoners; Human Rights Guarantee; Penitentiary.

\section{Abstrak}

Hak-hak warga binaan sebagai warga negara Indonesia yang hilang kemerdekaanya karena melakukan tindak pidana, haruslah dilakukan sesuai dengan hak asasi manusia. Pada praktiknya masih banyak belum terpenuhinya hak-hak warga binaan pemasyarakatan. Apakah ketentuan peraturan perundang-undangan telah sesuai dengan jaminan hak asasi manusia, apakah impelementasi pembinaan narapidana didalam lembaga pemasyarakatan telah sesuai dengan peraturan perundangundangan. Metode penelitian ini mengggunakan tipe penelitian hukum empiris dan normatif. Kesimpulan dari penelitian ini adalah pengaturan tentang sistem pemasyarakatan sebagai bagian dari integrated criminal justice system sudah cukup mengatur tentang pembinaan narapidana didalam lembaga pemasyarakatan bersepektif penghormatan hak asasi manusia narapidana. Impelementasi hak asasi manusia narapidana dalam pembinaan narapidana lembaga pemasyarakatan yang dijamin UndangUndang belum sepenuhnya dipenuhi oleh pemerintah dalam hal ini Dirjen Pemasyarakatan Kementrian Hukum dan Hak Asasi Manusia.

Kata Kunci: Narapidana; Jaminan Hak Asasi Manusia; Lembaga Pemasyarakatan. 


\section{Pendahuluan}

Pemidanaan berasal dari kata "pidana" yang diartikan pula dengan hukuman". Sehingga dapat dimaknai bahwa pemidanaan merupakan penghukuman. Dimana seseorang mendengar kata penghukuman, berarti seseorang tersebut diberikan penderitaan dengan maksud agar menimbulkan efek jera bagi pelaku dan sekaligus peringatan bagi masyarakat untuk tidak melakukan perbuatan serupa. ${ }^{2}$ Pengenaan pidana berhubungan erat dengan kehidupan seseorang dalam masyarakat, terutama menyangkut kepentingan benda hukum yang paling berharga bagi kehidupan di masyarakat, yaitu nyawa dan kemerdekaan atau kebebasannya. ${ }^{3}$

Salah satu tokoh terkemuka Van Bammelan penganut teori gabungan menyatakan "Pidana bertujuan membalas kesalahan dan mengamankan masyarakat. Tindakan bermaksud memelihara dan mengamankan tujuan. Sehingga pidana dan tindakan keduanya bertujuan mempersiapkan untuk mengembalikan terpidana ke kehidupan masyarakat", ${ }^{4}$

Pidana penjara dalam sejarahnya dikenal sebagai rekasi masyarakat terhadap adanya tindak pidana yang dilakukan oleh seorang pelanggar hukum. Seseorang dibuat tidak berdaya dan diasingkan secara sosial dari lingkungan semula. Menurut Dr. Saharjo, S.H. yang dikuti oleh C.I.Harsono, Bc.IP untuk memperlakukan warga binaan diperlukan landasan sistem Pemasyarakatan: ${ }^{5}$

"Bahwa tidak saja masyarakat diayomi terhadap perbuatan jahat oleh terpidana melainkan juga orang yang tersesat diayomi dengan memberikan kepadanya bekal hidup sebagai warga yang berguna dalam masyarakat. Dari pengayoman itu nyata bahwa penjatuhan pidana bukanlah tindakan balas dendam oleh negara. Tobat tidak dapat dicapai dengan penyiksaan melainkan dengan bimbingan. Terpidana juga tidak dijatuhi pada penyiksaan melainkan pada hilangnya kemerdekaan seseorang dan yang pada waktunya akan mengembalikan orang itu kepada masyarakat, yang mempunyai kewajiban terhadap orang terpidana itu dan masyarakat itu".

${ }^{1}$ Djoko Prakoso, Nurwachid, Pidana Mati Di Indonesia Dewasa Ini (Ghalia Indonesia 1984).[13].

2 ibid.

3 ibid.

${ }^{4}$ Andi Hamzah, Sistem Pidana dan Pemidanaan di Indonesia, (Pradnya Paramita1993).[32].

5 Harsono, Sistem Baru Pembinaan Narapidana, (Djambatan1995).[19]. 
Dari kutipan diatas sangatlah jelas bahwa tujuan dari pemberian sanksi pidana adalah untuk membina, membuat pelanggar hukum menjadi bertaubat dan sadar akan kesalahan yang dilakukannya, bukan berfungsi sebagai pembalasan. Pandangan dan pemahaman seperti itulah yang seharunya dimiliki dan sesuai dengan pandangan hidup bangsa yang terkandung dalam Pancasila, yang menjunjung tinggi nilai-nilai kemanusiaan.

Salah satu wadah atau institusi pembinaan bagi warga binaan pemasyarakatan adalah Lembaga Pemasyarakatan, hal ini harus dijalani oleh warga binaan pemasyarakatan sebagai akibat dari perbuatan pelanggaran hukum yang telah dilakukannya. Akan tetapi selain sebagai orang yang bersalah karena telah melanggar hukum, Warga Binaan Pemasyarakatan yang selanjutnya disingkat WBP adalah manusia ciptaan Tuhan yang memiliki harkat dan martabat yang perlu dihormati dan dihargai dengan pemberian perlakuannya harus tetap memperhatikan hak-hak yang dimilikinya sebagai manusia. Hak-hak warga binaan sebagai warga negara Indonesia yang hilang kemerdekaanya karena melakukan tindak pidana, haruslah dilakukan sesuai dengan hak asasi manusia.

Sebagai negara hukum hak-hak WBP harus dilindungi oleh hukum dan penegak hukum khususnya oleh petugas di Lembaga Pemasyarakatan, sehingga merupakan sesuatu yang harus dilaksanakan bagi negara hukum untuk menghargai hak-hak asasi narapidana sebagai warga masyarakat yang harus diayomi walapun telah melanggar hukum. Adanya pelanggaran HAM di dalam Lembaga Pemasyarakatan tentu mempengaruhi dalam proses pembinaan erat kaitannya dengan hak-hak yang harus diberikan bagi Warga Binaan Pemasyarakatan. Dalam Lembaga Pemasyarakatan proses pembinaan merupakan hal terpenting dalam mengukur berhasilnya proses pemasyarakatan, berdasarkan pasal 2 UU no 12 Tahun 1995 tentang pemasyarakatan, yaitu: "Sistem pemasyarakatan ditujukan untuk membentuk warga binaan agar menjadi manusia seutuhnya, menyadari kesalahan, tidak mengulangi perbuatan, sehingga dapat diterima kembali oleh masyarakat". Walaupun posisi narapidana sebagai warga binaan dalam posisi sebagai terhukum atau orang yang secara sah dirampas kemerdekaanya, bukan berarti hak-hak mereka selama dalam lembaga pemasyarakatan dapat di abaikan. 


\section{Pembinaan Narapidana Persepektif Penghormatan Hak Asasi Manusia Menurut Peraturan Perundang-Undangan}

Berbicara tentang perlindungan dan penegakan hak asasi manusia sebagai wujud hak-hak asasi seseorang tidak terlepas dari kehidupan manusia bermasyarakat, berbangsa dan bernegara yang menuntut adanya persamaan hak dalam perlakuan terhadap setiap manusia yang hidup didunia dan itu menjadi pendorong bagi lahirnya Declaration of Human Right (DUHAM) sebagai konsep perlakuan secara universal terhadap setiap manusia tanpa memandang perbedaan ras, agama, warna kulit, suku, bahasa dan sebagainya.

Negara dan para pemangku kewajiban lainya bertanggung jawab untuk mentaati hak asasi. Dalam hal ini, mereka harus tunduk pada norma-norma hukum dan standar yang tercantum di dalam instrument-instrument hak asasi manusia. Seandainya mereka gagal dalam melaksanakan tanggung jawabnya, pihak-pihak yang dirugikan berhak untuk mengajukan tuntutan secara layak, sebelum tuntutan itu diserahkan pada sebuah pengadilan yang kompeten atau ajudikator (penuntut) lain yang sesuai dengan aturan dan prosedur hukum yang berlaku.

Dari pengertian di atas, jelaslah sudah bahwa hak asasi manusia adalah hak yang melekat pada setiap manusia, terlepas apakah ia pejabat, rakyat jelata bahkan tersangka, terdakwa, tahanan maupun narapidana. Meskipun ia seorang tersangka, terdakwa, tahanan maupun narapidana sekalipun, harus tetap diperlakukan sebagai manusia yang mempunyai harkat, martabat serta harga diri. Mereka harus diperlakukan dengan cara manusiawi dan beradab. Harus diperlakukan dengan cara pendekatan yang manusiawi karena mereka bukanlah binatang dan bukan sampah masyarakat yang dapat diperlakukan dengan kasar, kejam dan bengis, merekapun ingin diakui dan dihargai, karena:

a. Sebagai manusia yang mempunyai derajat yang sama;

b. Mempunyai hak perlindungan hukum yang sama dengan manusia lain;

c. Mempunyai hak perlindungan hukum serta perlakuan keadilan yang sama di depan hukum 


\section{Pembinaan Narapidana}

Menurut kamus besar bahasa Indonesia (Poerwadarmita, 1987) pembinan adalah usaha, tindakan dan kegiatan yang dilakukan secara berdaya guna dan berhasil untuk memperoleh hasil yang lebih baik. Sedangkan menurut Romli, Pembinaan adalah segala usaha/tindakan yang berhubungan langsung dengan perencanaan, penyusunan, pengembangan dan penggunaan sesuatu secara berdaya guna dan berhasil guna. ${ }^{6}$

Dari definisi pembinaan diatas, jelas bagi kita maksud dari pembinaan itu sendiri dan pembinaan tersebut bermuara pada adanya perubahan kearah yang lebih baik, yang diawali dengan kegiatan perencanaan, pengorganisasian, pembiayaan, koordinasi, pelaksanaan dan pengawasan suatu pekerjaan untuk mencapai tujuan dengan hasil yang lebih baik.

Sementara itu ciri-ciri pembinaan menurut Mappa adalah: ${ }^{7}$

a. Pekerjaan yang dilakukan oleh seseorang dalam rangka mencapi setinggitingginya tingkat kematangan dan tujuan pembinaan;

b. Prosedur pembinaan dirancang sedemikian rupa agar tujuan yang hendak dicapai terarah;

c. Pembinaan sebagai pengatur proses belajar harus merancang dan memilih peristiwa yang sesuai dengan warga atau anak binaan;

d. Pembinaan diartikan sebagai usaha untuk menata kondisi yang pantas.

Drs. C.I. Harsono Hs, Bc.IP. menyatakan tujuan pembinaan adalah kesadaran (consciousness). ${ }^{8}$ Untuk memperoleh kesadaran dalam diri seseorang, maka seseorang harus mengenal diri sendiri. Diri sendiri yang akan mampu merubah seseorang untuk menjadi lebih baik, lebih maju, lebih positif. Tanpa mengenal diri sendiri, terlalu sulit bahkan tidak mungkin seseorang akan merubah diri sendiri. Bagaimana akan merubah sesuatu kalau tidak tahu persis apa sesuatu itu.

Undang-undang Nomor 12 Tahun 1995 Tentang Pemasyarakatan menjelaskan secara menyeluruh tentang pemasyarakatan. Menurut Undang-undang Nomor 12 Tahun 1995 Tentang Pemasyarakatan, lembaga Pemasyarakatan adalah tempat

\footnotetext{
${ }^{6}$ Romli Atmasasmita, Dari Pemendjaraan ke Pembinaan Narapidana (Alumni 1971).[5].

7 ibid.

${ }^{8}$ C.I. Harsono, Sistem Baru Pembinaan Narapidana (Djambatan1995).[48].
} 
untuk melaksanakan pembinaan narapidana dan anak didik pemasyarakatan, dimana proses pembinaan dibagi menjadi dua yaitu Pembinaan Kepribadian dan Pembinaan Kemandirian. Pembinaan Kepribadian meliputi: ${ }^{9}$

a. Pembinaan Kesadaran Beragama;

b. Pembinaan kesadaran Berbangsa dan bernegara;

c. Pembinaan kemampuan Intelektual (kecerdasan);

d. Pembinaan Kesadaran Hukum;

e. Pembinaan reintegrasi diri dengan masyarakat.

Sedangkan untuk pembinaan Kemandirian diberikan kepada pelanggar hukum melalui program-program sebagai berikut:

a. Keterampilan untuk usaha-usaha mandiri;

b. Keterampilan untuk mendukung usaha-usaha industri;

c. Keterampilan untuk mendukung usaha-usaha industri;

d. Keterampilan yang dikembangkan sesuai dengan bakatnya masing-masing;

e. Keterampilan untuk mendukung usaha-usaha industru pertanian dengan menggunakan teknologi.

\section{Hak Dasar Narapidana}

Sebagai narapidana atau warga binaan pemasyarakatan yang dirampas kemerdekaanya sebagai hukuman atas perbuatan pidana yang dilakukan, bukan berarti semua hak-hak narapidana ikut juga dirampas. Negara sebagai Pembina narapidana harus memastikan bahwa hak-hak dasar sebagai narapidana tetap harus dijamin selama proses pemasyarakatan. Tentunya hak-hak dasar narapidana haruslah sama antara narapidana satu dengan lainnya. Tidak ada narapidana yang memiliki hak lebih banyak atau lebih sedikit dari narapidana lainnya kecuali ada hal-hal tertentu yang dibenarkan menurut hukum untuk dibedakan.

Indonesia yang menganut filosofi reintegrasi dan pemasyarakatan dalam sistem pemidanaanya secara normatif juga mengatur mengenai pemenuhan hakhak narapidana sebagai salah satu faktor penting dalam proses pemidanaan. Sebagaimana terlihat di dalam Pasal 2 dan pasal 14 Undang-Undang Nomor 12 Tahun 1995.

${ }^{9}$ Peraturan Pemerintah Nomor 31 Tahun 1999 tentang Pembinaan dan Pembimbingan Warga Binaan Pemasyarakatan. 
Pasal 2 berbunyi sebagai berikut: Sistem pemasyarakatan diselenggarakan dalam rangka membentuk Warga Binaan Pemasyarakatan agar menjadi mausia seutuhnya, menyadari kesalahan, memperbaiki diri dan tidak mengulangi tindak pidana sehingga dapat diterima kembali oleh lingkungan masyarakat, dapat kembali aktif berperan dalam pembangunan dan dapat hidup secara wajar sebagai warga yang baik dan bertanggung jawab.

Pasal 14 berbunyi sebagai berikut:

Narapidana berhak:

a. Melakukan ibadah sesuai dengan agama atau kepercayaannya;

b. mendapat perawatan, baik perawatan rohani maupun jasmani;

c. mendapatkan pendidikan dan pengajaran;

d. mendapatkan pelayanan kesehatan dan makanan yang layak;mendapatkan pelayanan kesehatan dan makanan yang layak;

e. menyampaikan keluhan;

f. mendapatkan bahan bacaan dan mengikuti siaran media massa lainnya yang tidak dilarang;

g. mendapat upah atau premi atas pekerjaan yang dilakukan;

h. menerima kunjungan keluarga, penasehat hukum, atau orang tertentu lainnya;

i. mendapatkan pengurangan masa pidana (remisi);

j. mendapatkan kesempatan berasimilasi termasuk cuti mengunjungi keluarga;

k. mendapatkan pembebasan bersyarat;

1. mendapatkan cuti menjelang bebas; dan

m. mendapatkan hak-hak lain sesuai dengan peraturan perundang-undangan yang berlaku.

\section{Teori Pemidanaan}

Berhubungan dengan penjatuhan pidana kepada seseorang yang telah melakukan kesalahan, ada beberapa teori mengenai pemidanaan yang muncul abad ke-19, yaitu:

a. Teori pemidanaan absolut.

Teori pemidanaan absolut adalah aliran klasik yang hadir pada abad ke-18 merupakan reaksi dari ancient regime di Prancis dan Inggris yang mempunyai akibat ketidakpastian hukum, ketidaksamaan hukum dan ketidakadilan. Teori absolut pada dasarnya berfaham Indeterminisme tentang kehendak bebas (freewell) manusia yang menekankan pada perbuatan pelaku kejahatan sehingga dikehendaki ialah 
hukum pidana perbuatan (daad-strefrecht). ${ }^{10}$ Teori pemidanaan absolut memiliki karakteristik: ${ }^{11}$

a) Definisi hukum dari kejahatan;

b) Pidana harus sesuai dengan kejahatannya;

c) Doktrin kebebasan berkehendak;

d) Pidana mati untuk beberapa tindak pidana;

e) Tidak ada riset empiris; dan

f) Pidana yang ditentukan secara pasti.

b. Teori pemidanaan relatif.

Teori pemidanaan relatif menyatakan bahwa pemidanaan dikenakan berdasarkan manfaat apa yang akan dicapai dari pemidanaan tersebut. Teori ini memiliki sifat utilitarian yang mengutamakan manfaat dari suatu penegakan hukum, yang ingin dicapai dari pemidanaan teori ini adalah preventif atau pencegahan suatu tindak pidana agar tidak terjadi lagi dan perlindungsn bagi masyarakat, sehingga sifatnya menakut-nakuti pelaku maupun calon pelaku agar tidak melakukan suatu tindak pidana. Teori ini dikemukakan oleh tokoh Seneca dan Van Hamel. Teori relatif memiliki karakteristik: ${ }^{12}$

a. Memiliki tujuan untuk melakukan pencegahan;

b. Pencegahan bukanlah pidana akhir, tapi merupakan sarana untuk mencapai tujuan yang lebih tnggi yaitu kesejahteraan masyarakat;

c. Hanya Pelanggaran-Pelanggaran hukum yang dapat dipersalahkan kepada si pelaku saja yang memenuhi syarat untuk adanya pidana;

d. Pidana harus ditetapkan berdasarkan tujuannya sebagai alat untuk pencegahan kejahatan; Pidana berutujuan ke depan, pidana dapat mengandung unsur pencelaan, tetapi baik unsur pencelaan maupun unsur pembalasan tidak dapat diterima apabila tidak dapat membantu pencegahan kejahatan untuk kepentingan kesejahteraan masyarakat.

c. Teori campuran atau gabungan

Teori campuran atau gabungan pada perinsipnya mengkombinasikan teori pemidanaan absolut dan teori pemidanaan relatif. Dalam teori campuran

\footnotetext{
${ }^{10}$ Simeon Tonggengbio, 'Sistem Pemidanaan Dalam Penjatuhan Pidana Penjara Berdasrkan Undang-Undang Nomor 12 Tahun 1995 Tentang Pemasyarakatan’ (2016) Volume IV No. 3 Lex Administratum.[26].

${ }^{11}$ ibid.

${ }^{12}$ E.Z. Leasa, 'Penerapan Sanksi Pidana dan Sanksi Tindakan Dalam Kebijakan Legislasi' (2010) 16 Jurnal Sasi.[51-58].
} 
memperhatikan pembalasan, prevensi general dan perbaikan sebagai tujuan pidana. Sehingga tujuan pemidanaannya adalah mencegah terjadinya pengulangan tindak pidana, mencegah masyarakat melakukan tindak pidana sebagaimana pelaku tindak pidana, menghindari balas dendam, mendidik terpidana, memelihara perdamaian, memperkuat kembali nilai-nilai sosial teori campuran atau gabungan lahir sebagai jalan keluar dari teori pemidanaan relatif maupun pemidanaan absolut. Teori gabungan didasarkan pada tujuan pembalasan dan mempertahanakan ketertiban masyarakat yang diterapkan secara sinergis. Teori gabungan atau campuran dianut oleh tokoh Richard Schmid, Merkel, kohler, Beling, Binding dan Rossi.

\section{Regulasi yang Berkaitan dengan Lembaga Pemasyarakatan Indonesia}

Lahirnya Undang-Undang Nomor 12 Tahun 1995 Tentang Pemasyarakatan (selanjutnya disebut UU Pemasyarakatan) merupakan tonggak bersejarah pembangunan sistem pemasyarakatan dalam sistem hukum pidana Indonesia utamanya dalam sistem pemidanaan. Sebelum Undang-Undang ini lahir, Indonesia dalam sistem pemidanaannya masih mengacu pada ketentuan-ketentuan jaman kolonial Belanda dengan beberapa perubahan yang tentunya masih menekankan pola-pola pendekatan pembalasan dan penjeraan dalam operasional pemidanaannya. Berlakunya ketentuan jaman kolonial tersebut terlihat dalam ketentuan penututp Pasal 53 UU No. 12 Tahun 1995 yang menyatakan beberapa ketentuan mengenai pemasyarakatan menjadi tidak berlaku dengan berlakunya UU Pemasyarakatan.Berdasarkan Pasal 53, Pada saat mulai berlakunya Undangundang ini:

1) Ordonnantie op de Voorwaardelijke Invrijheidstelling (Stb. 1917-749, 27 Desember 1917 jo. Stb. 1926-488) sepanjang yang berkaitan dengan pemasyarakatan;

2) Gestichtenreglement (Stb. 1917-708, 10 Desember 1917);

3) Dwangopvoedingsregeling (Stb. 1917-741, 24 Desember 1917); dan

4) Uitvoeringsordonnantie op de Voorwaardelijke Veroordeeling (Stb. 1926-487, 6 November 1926) sepanjang yang berkaitan dengan pemasyarakatan; dinyatakan tidak berlaku. 
Tujuan utama penyelenggaran sistem pemasyarakatan pasca berlakunya UU Pemasyarakatan adalah dalam rangka membentuk Warga Binaan Pemasyarakatan agar menjadi manusia seutuhnya, menyadari kesalahan, memperbaiki diri dan tidak mengulangi tindak pidana sehingga dapat diterima kembali oleh lingkungan masyarakat, dapat aktif berperan dalam pembangunan dan dapat hidup secara wajar sebagai warga yang baik dan bertanggung jawab (Pasal 2 UU Pemasyarakatan). Dalam rangka mencapai tujuan tersebut, pembentuk UU Pemasyarakatan percaya bahwa proses rehabilitasi dan reintegrasi warga binaan bisa tercapai jika proses tersebut tetap menjunjung tinggi harkat dan martabat warga binaan, walaupun warga binaan berada dalam posisi yang dapat dikatakan sangat lemah yakni sebagai narapidana yang telah dinyatakan secara sah dan meyakinkan bersalah melakukan tindak pidana sehingga layak dihukum.

Pengaturan Pasal 5 UU Pemasyarakatan memperlihatkan bahwa asas-asas yang menjiwai sistem pemasyarakatan adalah asas-asas yang mengedepankan pembinaan warga binaan yang bersepektif penghormatan hak asasi manusia, pengayoman dan pembimbingan walaupun status mereka sebagai narapidana. Sebagai contoh dalam pasal 5 huruf fUU Pemasyarakatan menegaskan asas bahwa kehilangan kemerdekaan merupakan satu-satunya penderitaan bagi narapidana dalam proses pemasyarakatan yang mereka jalani.

Pengaturan penjamin hak narapidana sebagai bagian penting dalam proses pembinaan di lembaga pemasyarakatan kemudian diikuti dengan beberapa peraturan pelaksana yang antara lain, sebagai berikut:

a. Peraturan pemerintah Nomor 32 Tahun 1999 jo Peraturan pemerintah Nomor 28 Tahun 2006 Tentang Tata Cara dan Pelaksanaan Hak Warga Binaan;

b. Peraturan pemerintah Nomor 13 Tahun 1999 Tentang Pembinaan dan Pembimbingan Warga Binaan Pemasyarakatan;

c. Peraturan Pemerintah Nomor 57 Tahun 1999 Tentang Kerjasama Penyelenggaraan Pembinaan dan Pembimbingan Warga Binaan Pemasyarakatan;

d. Peraturan pemerintah Nomor 58 Tahun 1999 Tentang Syarat-syarat Dan Tata Cara Pelaksanaan Wewenang, Tugas dan Tanggung Jawab Perawatan Tahanan. 
Regulasi terkait pembinaan narapidana,di samping dalam bentuk peraturan pemerintah secara teknis juga diaturan dalam bentuk peraturan yang lebih rendah yaitu:

a. Peraturan Menteri Hukum dan Hak Asasi Manusia R.I. Nomor: M.01 Pk.04.10. Tahun 2007 Tentang Wali Pemasyarakatan;

b. Peraturan Menteri Hukum Dan Hak Asasi Manusia Republik Indonesia Nomor M.2.Pk.04-10 Tahun 2007 jo Peraturan Menteri Hukum Dan Hak Asasi Manusia Republik Indonesia Nomor: 02.P14.95.65 Tahun 2010 Tentang Syarat Dan Tata Cara Pelaksanaan Asimilasi, Pembebasan Bersyarat, Cuti Menjelang Bebas dan Cuti Bersyarat;

c. Peraturan menteri Hukum Dan Hak Asasi Manusia Republik Indonesia Nomor 406 Tahun 2009 Tetang Pedoman Makanan Warga Binaan Pemasyarakatan.

\section{Pembinaan Narapidana Ditinjau dari Hukum Internasional}

Sebagai konsekuensi pengadopsian UN Standard for Prisoners tersebut sudah barang tentu Indonesia wajib menerapkan pengakuan hak-hak dasar bagi warga binaan baik dalam segi aturan dan pengimplementasian di masyarakat. Dalam sub bab ini akan diuraikan standar minimum apa yang diatur dalam UN Standard for Prisoners dan implementasinya dalam aturan di Indonesia, sedangkan implementasi di lapangan akan diuraikan dalam bab tersendiri.

Prinsip dasar dalam UN Standard for Prisoners mengtur bahwa diskriminasi suku, agama, ras, bahasa, jenis kelamin, pandangan politik dan golongan dalam memperlakukan narapidana adalah dilarang termasuk didalamnya penghormatan atas pandangan agama dan pandangan moral narapidana. Prinsip dasar dalam UN standard tersebut sejalan dengan asas sistem pembinaan pemasyarakatan sebagaimana tercantum dalam Pasal 5 UU Pemasyarakatan. Berikut adalah perbandingan terkait pembinaan Narapidana antara Hukum Internasional dan Hukum Nasional. 


\begin{tabular}{|c|c|c|}
\hline No & Tentang & Hukum Internasional \\
\hline 1. & $\begin{array}{l}\text { Pencatatan } \\
\text { (Register) }\end{array}$ & $\begin{array}{l}\text { Dalam UN Standard diatur } \\
\text { bahwa: } \\
\text { (1) In everyplace where persons } \\
\text { are imprisoned there shall } \\
\text { be kept a bound registration } \\
\text { book with numbered pages } \\
\text { in which shall be entered } \\
\text { in respect of each prisoner } \\
\text { received: } \\
\text { (a) Information concerning } \\
\text { his identity; } \\
\text { (b) The reasons for his } \\
\text { commitment and the } \\
\text { authority therefor; } \\
\text { (c) The day and hour of his } \\
\text { admission and release. } \\
\text { (2) No person shall be received } \\
\text { in an institution without a } \\
\text { valid commitment order of } \\
\text { which the details shall have } \\
\text { been previously entered in } \\
\text { the register. }\end{array}$ \\
\hline
\end{tabular}

2. Pemisahan dan Pengkategorian Narapidana (Separation Categories)
1. The different categories of prisoners shall be kept in separate institutions or parts of institutions taking account of their sex, age, criminal record, the legal reason for their detention and the necessities of their treatment. Thus,

(a) Men and women shall so far as possible be detained in separate institutions; in an institution which receives both men and women the whole of the premises allocated to women shall be entirely separate;

(b) Untried prisoners shall be kept separate form convicted prisoners;

(c) Persons imprisoned for debt and other civil prisoners shall be kept separate form persons imprisoned by reason-of a criminal offence;

(d) Young prisoners shall be kept separate form adults.
Standar tersebut diatas telah diatur dalam sistem pemasyarakatan Indonesia melalui pengaturan dalam pasal 12 UU Pemasyarakatan.

(1) Dalam rangka pembinaan terhadap Narapidana di LAPAS dilakukan penggolongan atas dasar:

a. Umur;

b. Jenis kelamin;

c. Lama pidana yang dijatuhkan;

d. Jenis kejahatan; dan

e. Kriteria lainnya sesuai dengan kebutuhan atau perkembangan pembinaan.

(2) Pembinaan Narapidana Wanita di LAPAS dilaksanakan di LAPAS Wanita. 
3. Akomodasi (Accomodation)
All accmmodation provided for the use of prisoners and in particular all sleeping accommdation shall meet all requirements of health, due regard being paid to climatic conditions and particularly to cubic content of air, minimum floor space, lighting, heating and ventilation

\section{Kebersihan Pribadi, Pakaian dan Tempat Tidur (Personal Hygiene, Clothing and Bedding)}

\section{Makanan (Food)}

- Prisoners shall be required to keep their persons clean, and to this end they shall be provided with water and with such toilet articles as are necessary for health and cleanliness (article 15)

- Every prisoner who is not allowed to wear his own clothing shall be provided with an outfit of clothing suitable for the climate and adequate to keep him in good health. Such clothing shall in no manner be degrading or humiliating (article 17)

Every prisoner shall, in accordance with local or national standards, be provided with a separate bed, and with separate and sufficient bedding which shall be clean when issued, kept in good order and changed often enough to ensure its cleanliness (article 19)

\section{Pasal $20 \quad$ UN Standard} menegaskan bahwa:

(1) Every prisoner shall be provided by the administration at the usual hours with food of nutritional value adequate for health and strength, of wholesome quality and well prepared and served.

(2) Drinking water shall be available to every prisoner whenever he needs it.
Pengaturan yang berbicara tentang jaminan akomodasi layak justru ditemukan dalam Surat Edaran Direktur Jendral Pemasyarakatan Departement Kehakiman Nomor E.PS.01.0616 perihal Penentuan Daya Muat/Kapasitas Lapas/Rutan/ Cabang Rutan, tertanggal 23 Oktober 1996. Dalam surat edaran tersebut diatur tentang standarisasi daya muat lembaga pemasyarakatan yang diukur melalui dua standar.

Dalam UU Pemasyarakatan jaminan atas standar tersebut secara normatif diatur dalam Pasal 14 tentang jaminan hak narapidana mendapatkan perawatan jasmani dan rohani. Pengaturan pelaksana atas Pasal 14 tersebut terdapat dalam Peraturan Pemerintah Nomor 32 Tahun 1999 jo Peraturan Pemerintah Nomor 28 Tahun 2006 Tentang Tata Cara dan Pelaksanaan Hak Warga Binaan yang didalamnya menegaskan bahwa setiap narapidana dan anak didik pemasyarakatan berhak mendapatkan perawatan jasmani antara lain:
a. Pemberian pakaian; dan
perlengkapan b. Pemberian perlengkapan tidur dan mandi.


Pengaturan pernerintah tersebut di atas diterjemahkan lebih lanjut dalam Permenkumham RI No.406 tahun 2009 Tentang Pedoman Makanan Warga Binaan Pemasyarakatan.

6. Olah raga dan
Rekreasi (Exercise
and sport) $\begin{aligned} & \text { Pasal } 21 \text { UNegaskan: } \\ & \text { (1) Every prisoner who is } \\ & \text { not employed in outdoor work } \\ & \text { shall have at least one hour } \\ & \text { of suitable exercise in the } \\ & \text { open air daily if the weather } \\ & \text { permits. } \\ & \text { (2) Young prisoners, } \\ & \text { and others of suitable age } \\ & \text { and physique, shall receive } \\ & \text { physical and recreational } \\ & \text { training during the period of } \\ & \text { exercise. To this end space, } \\ & \text { installations and equipment } \\ & \text { should be provided. }\end{aligned}$

7. Pelayanan

Pasal 22 menyatakan:

Kesehatan

(Medical services)

(1) At every institution there shall be available the services of at least one qualified medical officer who should have some knowledge of psychiarty. The medical services should be organized in close relationship to the general health administration of the community or nation. They shall include a psychiatric service for the diagnosis and, in proper cases, the treatment of states of mental abnormality.

\section{Jaminan \\ Informasi \\ dan Keluhan \\ Narapidana \\ (Information To \\ And Complaint By \\ Prisoners)}

UUPemasyarakatan teelah menjamin kesempatan dalam berekreasi dan olah raga melalui jaminan hak atas perawatan jasmani dan rohani sebagaimana di atur dalam Pasal 14 huruf b UU Pemasyarakatan. Pasal 7 PP No. 32 Tahun 1999 jo PP No. 28 Tahun 2006 menegaskan bahwa setiap narapidana dan anak didik pemasyarakatan berhak mendapatkan perawatan jasmani berupa pemberian kesempatan melakukan olah raga dan rekreasi.

Jaminan pelayanan kese-hatan termasuk dalam jaminan hak narapidana yang diatur dalam UU Pemasyarakatan Pasal 14 ayat 1 huruf b. Peraturan Pemerintah Nomor 32 Tahun 1999 jo Peraturan Pemerintah Nomor 28 Tahun 2006 Tentang Tata Cara dan Pelaksanaan Hak Warga Binaan, Pasal 14 sampai dengan Pasal 17 mengatur secara rinci mengenai pelaksanaan jaminan atas akses kesehatan narapidana.

Hak narapidana yang dijamin dalam Pasal 14 ayat 1 huruf e UU Pemasyarakatan mengatur tentang hak narapidana untuk menyampaikan keluhan. Keluhan tersebut disampaikan jika narapidana merasakan bahwa perlakuan yang menyimpang dari aturan baik dari sesama narapidana maupun petugas lembaga pemasyarakatan sebagaimana diatur dalam PP No. 32 Tahun 1999 jo PP No. 28 Tahun 2006 Pasal 26.
35. (1) Every prisoner on adminission shall be provided with written information about the regulations governing the treatment of prisoners og his category, the disci-plinary requirments of the institution, the authorized methods of seeking information and making complaints, and all such other matters as are necessary to enable him to understand both his rights and his obligations and to adapt himself to the life of the institution. 
9. Jaminan

Untuk Tetap

Berhubungan

Dengan Dunia

Luar dan Akses

Terhadap Buku-

Buku Bacaan

(Contact with the outside world and

Books)
37. Prisoners shall be allowed under necessary supervision to communicate with their family and reputable friends at regular intervals, both by correspondence and by receiving visits.

39. Prisoners shall be kept informed regularly of the more important items of news by the reading newspapers, periodicals or special institutional publicatons, by hearing wireless transmissions, by lectures or by any similar means as authorized or controlled by the administration.

40. Every institution shall have a library for the use of all categories of prisoners, adequately stocked with both recreational and instructional books, and prisoners shall be encouraged to make full use og it.

\section{Jaminan Menjalankan Syariat Agama (Religion)}

41. (1) If the institution contains a sufficient number of prisoners of the same religion, a qualified representative of that religion shall be appointed or approved. If the number of prisoners justifies it and conditions permit, the arrangement should be on a full-time basis.

(2) A qualified representative appointed or approved under paragraph (1) shall be allowed to hold regular services and to pay pastoral visits in private to prisoners of his religon at proper times.

(3) Access to a qualified representative of any religion shall not be refused to any prisoner. On the other hand, if any prisoner should object to a visit of any religious representative, his attitude shall be fully respected.
Pasal 14 ayat 1 huruf $\mathrm{f}$ dan $\mathrm{h}$ UU Pemasyarakatan berturutturut mengatur mengenai hak narapidana untuk mendapatkan bahan bacaan serta mengikuti berita media massa dan hak untuk dikunjungi keluarga, penasehat hukum dan orang tertentu lainnya. Pengaturan tersebut sama dengan apa yang disyaratkan dalam $U N$ Standard.

\begin{abstract}
Undang-Undang Pemasyarakatan memandang bahwa pendekatan keagamaan atau pendekatan rohani merupakan pendekatan pembimbingan narapidana yang sangat efektif dlam mencapai tujuan pemidanaan. Hak menjalankan ibadah sesuai agamannya ini menjadi hak yang pertama dijamin dalam Pasal 14 ayat 1 huruf a UU Pemasyarakatan. Jaminan agama ini juga tercemin dalam hak narapidana yang lain yaitu hak mendapatkan perawatan rohani yang juga merupakan hak narapidana sebagaimana diatur dalam Pasal 14 ayat 1 huruf $b$.
\end{abstract}




\begin{tabular}{|c|c|c|c|}
\hline & & $\begin{array}{l}\text { 42. So far as practicable, every } \\
\text { prisoner shall be allowed to } \\
\text { satisfy the need of his religious } \\
\text { life by attending the services } \\
\text { provided in the institution and } \\
\text { having in his possession the } \\
\text { books of religious observance } \\
\text { and instruction of his } \\
\text { denomination. }\end{array}$ & \\
\hline 11. & $\begin{array}{l}\text { Jaminan } \\
\text { Pemberitahuan } \\
\text { Kematian, Sakit, } \\
\text { Pemindahan } \\
\text { Dan Sebagainya } \\
\text { (Notification Of } \\
\text { Death, Illness, } \\
\text { Transfer, Etc) }\end{array}$ & $\begin{array}{l}\text { 44. (1) Upon the death or } \\
\text { serious illness of, or serious } \\
\text { injury to a prisoner, or his } \\
\text { removal to an institution } \\
\text { for the treatment of mental } \\
\text { affection, the director shall } \\
\text { at once inform the spouse, } \\
\text { if the prisoner is married, } \\
\text { or the nearest relative and } \\
\text { shall in any event inform } \\
\text { any other person previously } \\
\text { designated by the prisoner. } \\
\text { (2) A prisoner shall be informed } \\
\text { at once of the death or } \\
\text { serious illness of any near } \\
\text { relative. In case of the } \\
\text { critical illness of a near } \\
\text { relative, the prisoner should } \\
\text { be authorized, whenever } \\
\text { circumstances allow, to go } \\
\text { to his bedside either under } \\
\text { escort or alone. } \\
\text { (3) Everyprisoner shall havethe } \\
\text { right to inform at once his } \\
\text { family of his imprisonment } \\
\text { or his transfer to another } \\
\text { institution. }\end{array}$ & $\begin{array}{l}\text { PP No. } 32 \text { Tahun } 1999 \text { jo PP } \\
\text { No. } 28 \text { Tahun } 2006 \text { Pasal } 18 \\
\text { mengatur tentang jaminan } \\
\text { hak narapidana ketika } \\
\text { sakit atau meninggal dunia } \\
\text { untuk diberitahukan kepada } \\
\text { keluarganya. } \\
\text { PP No. } 31 \text { Tahun } 1999 \text { Pasal } \\
53 \text { mengatur tentang jaminan } \\
\text { pemberitahuan kepada keluarga } \\
\text { dalam kasus pemindahan lokasi } \\
\text { lembaga pemasyarakatan } \\
\text { terhadap seseorang narapidana. }\end{array}$ \\
\hline
\end{tabular}

\section{Pembinaan Narapidana Perspektif Penghormatan Hak Asasi Manusia Di}

\section{Lembaga Pemasyarakatan}

Kehadiran pemasyarakatan secara hakiki memiliki setidaknya dua fungsi: ${ }^{13}$

a. Pertama; sebagai perwujudan politik hukum nasional untuk mengganti peraturan perundang-undangan produk masa kolonial. Dengan Undangundang Pemasyarakatan ini, maka peraturan Kepenjaraan dari masa kolonial seperti "Getistichten reglement" dicabut dan dinyatakan tidak berlaku lagi.

${ }^{13}$ NN, 40 Tahun Pemasyarakatan Mengukir Citra Profesionalisme, (Direktorat Jendral Pemasyarakatan Departemen Kehakiman dan Hak Asasi Manusi Republik Indonesia 2004).[37]. 
Dengan demikian lahirlah suatu hukum nasional yang baru yang mengatur pemasyarakatan;

b. Kedua; sebagai satu pengukuhan hukum atas sistem pemasyarakatan yang telah dijalankan sejak lebih dari tiga puluh tahun yang lalu yang selama ini diatur secara "ad hoc" dalam berbagai peraturan dan kebijakan. Dengan undangundang pemasyarakatan ini maka makin kokoh usaha-usaha mewujudkan satu sistem pemasyarakatan yang bersumber dan berdasarkan Pancasila dan UUD NRI Tahun 1945.

Secara garis besar menurut Sunaryo pembinaan narapidana, meliputi: ${ }^{14}$

1. Pembinaan kesadaran beragama. Usaha ini diperlukan agar dapat memperteguh iman para narapidana terutama memberi pengertian agar narapidana dapat menyadari akibat-akibat dari perbuatan-perbuatan yang benar dan perbuatan yang salah;

2. Pembinaan kesadaran berbangsa. Usaha ini diperlukan untuk menyadarkan mereka agar dapat menjadi warga negara yang baik, yang dapat berbakti bagi bangsa dan negaranya;

3. Pembinaan kemampuan intelektual (kecerdasan). Usaha ini diperlukan agar pengetahuan serta kemampuan berpikir narapidana semakin meningkat sehingga dapat menunjang kegiatan-kegiatan positif yang diperlukan selama masa pembinaan;

4. Pendidikan kemandirian/keterampilan. Keterampilan untuk mendukung usaha mandiri, misalnya industri rumah tangga;

5. Pembinaan kesadaran hukum. Pembinaan kesadaran hukum narapidana dilaksanakan dengan memberikan penyuluhan hukum yang bertujuan untuk mencapai kadar kesadaran hukum yang tinggi;

6. Penyuuhan hukum dilakukan secara langsung. Metode pendekatan yang diutamakan adalah metode persuasif, edukatif komunikatif, dan akomodatf (PEKA);

7. Pembinaan pengintegrasian diri dengan masyarakat. Pembinaan di bidang ini dapat dikatakan juga sebagai pembinaan kehidupan sosial kemasyarakatan, yang bertujuan pokok agar bekas narapidana mudah diterima kembali oleh masyarakat lingkungannya;

8. Kegiatan rekreasi yang diarahkan pada penumpukan kesegaran jasmani dan rohani, melalui: Oleh raga, hiburan, membaca, dll;

9. Perpustakaan. Untuk mengisi waktu luang dn guna menyalurkan minat baca maka disediakan perpustakaan.

${ }^{14}$ Thomas Sunaryo, Diktat/Materi Kuliah Sistem Pemasyarakatan Indonesia (Penologi 2001).[58]. 
Penulis berpendapat bahwa bentuk pembinaan berdasarkan prinsip pemasyarakatan, meliputi pembinaan kepribadian dan kemandirian ditujukan agar warga binaan pemasyarakatan tidak mengulangi kejahatan dan mentaati peraturan hukum, serta pembinaan huungan antara narapidana dengan masyarakat luar agar dapat berdiri sendiri dan diterima sebagai anggota masyarakat.

\section{Implementasi Pembinaan di Dalam Lembaga Pemasyarakatan Klas I Tangerang}

Impelementasi jaminan hak asasi manusia narapidana dalam pembinaan narapidana lembaga pemasyarakatan yang telah di atur peraturan perundangundangan yang berlaku, menurut penelitian yang dilakukan oleh Ahmad Hudzaifi pada tahun 2017 di Lembaga Pemasyarakatan Klas I Tangerang belum dapat terimpelementaskan sepenuhnnya di lapangan, seperti ${ }^{15}$ :

a. Tujuan sistem pemasyarakatan

Dimana berdasarkan Pasal 2 Undang-Undang Pemasyarakatan Nomor 12 Tahun 1995 menyatakan bahwa system pemasyarakatan diselenggarakan untuk membentuk Warga Binaan Pemasyarakatan agar menjadi manusia seutuhnya, menyadari kesalahan, memperbaiki diri dan tidak mengulangi tindak pidana sehingga dapat diterima kembali oleh lingkungan masyarakat, dapat aktif berperan dalam pembangunan dan dapat hidup secara wajar sebagai warga yang baik dan bertanggung jawab. Namun dalam pelaksanaanya masih banyak narapidana residivis didalam lembaga pemasyarakatan Kelas I Tangerang menyatakan sebabnya melakukan kembali tindak pidana lebih disebabkan oleh lingkungan ketika ia bergaul dengan narapidana lain saat berada di LAPAS. Dengan demikian lembaga pemasyarakatan yang bertujan untuk membina narapidana menjadi lebih baik, malah justru menjadikan lembaga pembinaan menjadi tempat berlangsungnya tukar-menukar informasi, pengalaman, bahkan budaya criminal yang dapat melahirkan narapidana residivis di kemudian hari.

\footnotetext{
15 Ahmad Hudzaifi, 'Prisonisasi dan Pembelajaran Kejahatan Di Lembaga Pemasyarakatan (Studi Kasus: Lembaga Pemasyarakatan Klas I Tangerang)', (Repository UIN Syarif Hidayatullah 2017) < http://repository.uinjkt.ac.id/dspace/handle/123456789/40938> Accessed 4 Agustus 2020.
} 
b. Tidak meratanya pelaksanaan program pembinaan

Dimana berdasarkan Pasal 5 Undang-Undang Pemasyarakatan Nomor 12 Tahun 1995 menyatakan bahwa Sistem pembinaan pemasyaraatan dilaksanakan berdasarkan asas:

a. Pengayoman;

b. Persamaan perlakuan dan pelayanan;

c. Pendidikan;

d. Pembimbingan;

e. Penghormatan harkat dan mrtabat manusia;

f. Kehilangan kemerdekaan merupakan satu-satunya penderitaan; dan

g. Terjaminya hak untuk tetap berhubungan dengan keluarga dan orang-orang tertentu.

Dalam pelaksanaanya tidak semua narapidana mendapatkan program pembinaan secara merata hal ini di sebabkan baik faktor individu narapidana yang tidak ingin mengikuti program pembinaan kepribadian maupun program kemandirian dan pihak lembaga pemasyarakatan ketika tidak tersedianya sarana prasaana penunjang yang mencukupi. Hal ini jelas merupakan tidak terpenuhinya asas Persamaan perlakuan dan pelayanan.

\section{Implementasi Pembinaan di Dalam Lembaga Pemasyarakatan Klas II A} Yogyakarta

Implementasi jaminan hak asasi manusia narapidana dalam pembinaan narapidana lembaga pemasyarakatan Klas II A Yogyakarta, menurut penelitian yang dilakukan oleh Aroma Elmina Martha dan Chandra Khoirunnas. Pada tahun 2018 di lembaga pemasyarakatan Klas II A Yogyakarta belum dapat terimplementasikan sepenuhnya di lapangan, seperti: ${ }^{16}$

Terjadinya tindak kekerasan yang ada di Lembaga Pemasyarakatan Klas II A Yogyakarta. Dimana berdasarkan Peraturan Menteri Hukum dan Hak Asasi Manusia Nomor 6 Tahun 2013 Pasal (3) huruf j bahwa melakukan tindak kekerasan kepada

\footnotetext{
${ }^{16}$ Aroma Elmina Martha, Chandra Khoirunnas, 'Penganiayaan Terhadap Narapidana Pelaku Perkosaan Yang Mengalami Label Negatif Di Lembaga Pemasyarakatan (Studi Di Lembaga Pemasyarakatan Wirogunan Yogyakarta)' (2018) 4 VeJ.[388].
} 
sesama penghuni maupun petugas dikategorikan sebagai pelanggaran disiplin tingkat berat. Oleh sebab itu bentuk tindak kekerasan dan pelanggaran terhadap ketentuan maka dijatuhi sanksi bagi pelanggarnya. Namun demikian yang terjadi dalam praktik tidak lah sesuai dengan ketentuan yang telah diatur, dimana narapidana yang melakukan tindak kekerasan terhadap narapidana lainnya hanya diberikan teguran lisan ketika diketahui oleh petugas pemasyarakatan jadi buikan merupakan proses penjatuhan hukuman disiplin berat, sebab proses yang panjang dan rumit dari pemeriksaan terhadap mereka yang melanggar. Bahkan sering kali dalam menjaga ketertiban lembaga pemasyarakatan kepada pelanggaran yang dilakukan oleh warga binaan pemasyarakatan atau narapidana dengan menggunakan cara kekerasan kepada warga binaan pemasyarakatan atau narapidana.

Sehingga ketika belum terimpelementasinya hak-hak narapidana dalam pembinaan narapidana lembaga pemasyarakatan dapat dimungkinkan dalam memenuhi kebutuhanya tersebut warga binaan pemasyarakatan melakukan tindakan penyimpangan yang berdampak pada tindakan kriminal di dalam Lembaga Pemasyarakatan. Oleh Karena itu perlu adanya perhatian pemerintah akan hal tersebut sebagaimana ditegaskan dalam Pasal 28 I Undang-Undang Dasar Negara Republik Indonesia Tahun 1945 yang menyatakan bahwa Perlindungan, Pemajuan Penegakan dan pemenuhan Hak Asasi Manusia adalah tanggung jawab negara, terutama Pemerintah.

\section{Pembinaan di Lembaga Pemasyarakatan Klas II B Mojokerto}

Hak-hak bersyarat seperti hak cuti mengunjungi keluarga, remisi, asimilasi, pembebasan bersyarat, dan sebagainya, maka kebijakan Lapas berdasarkan ketentuan peraturan perundang-undangan yang berlaku, seperti memperhatikan perilaku Narapidana selama masa pembinaan, guna Narapidana memahami tentang hak-hak bersyarat mereka, pihak Lapas melakukan sosialiasi dan transparansi secara terus-menerus mengenai prosedur pengajuannya melalui spanduk besar yang ditempelkan di dekat aula, bahkan masih dilakukan masa pengenalan lingkungan (mapenaling) selama kurang lebih satu minggu bagi Narapidana yang baru masuk 
atau pindah dari Lapas lain. ${ }^{17}$

Meskipun telah ada upaya sosialisasi yang dilakukan oleh Lapas secara terus-menerus, narapidana masih menganggap bahwa informasi yang diberikan oleh petugas Lapas masih kurang maksimal, khususnya mengenai transparansi pengumuman Narapidana yang memperoleh remisi, sehingga Narapidana tidak mengetahui siapa saja dan kapan mendapatkan hak tersebut.

Adapun permasalahan yang dihadapi Narapidana berkaitan dengan penerapan hak-hak bersyarat yakni: (1) Informasi tidak diterima dengan maksimal (kurang transparansi) mengenai pengumuman Narapidana yang memperoleh remisi; ${ }^{18}(2)$ Narapidana ada yang tidak mendapatkan remisi khusus; ${ }^{19}$ (3) Jarak waktu antara pengajuan Pembebasan Bersyarat (PB) dengan turunnya surat penetapan pemberian PB sangat lama, ada Narapidana yang hingga hampir setahun belum juga mendapatkan penjelasan; ${ }^{20}$ (4) Narapidana belum sepenuhnya mengetahui dan memahami mengenai Peraturan Pemerintah No. 28 Tahun 2006, apakah berlaku surut atau tidak; ${ }^{21}$ (5) Narapidana tidak mengetahui dan paham mengenai pemberlakuan Peraturan Pemerintah No. 99 Tahun 2012. Belum ada sosialisasi terkait dengan Peraturan Pemerintah No. 99 Tahun 2012 tersebut. ${ }^{22}$

Adapun faktor penghambat penerapan hak-hak Narapidana di Lapas, antara lain: (1) Jumlah Narapidana 615 yang melebihi kapasitas Lapas 344; (2) Kurangnya anggaran untuk penerapan hak-hak Narapidana di Lapas; dan (3) Kurangnya sinergisitas antar instansi dalam penerapan hak-hak Narapidana. Masih ada juga beberapa Narapidana merasa sulit memperoleh Remisi maupun PB.berikut faktor penyebabnya ialah: (1) Adanya Narapidana yang sulit/tidak dapat memberikan jaminan dari keluarga sebagai salah satu syarat dalam pengajuan Remisi dan hakhak bersyarat lainnya; (2) Adanya Narapidana yang belum menerima surat putusan

\footnotetext{
${ }^{17}$ Hasil wawancara dengan Kalapas Klas IIB Mojokerto pada 22 Agustus 2020.

${ }^{18}$ Hasil wawancara dengan S, narapidana Lapas Klas IB Mojokerto pada 22 Agustus 2020.

${ }^{19}$ Hasil wawancara dengan H, narapidana Lapas Klas IIB Mojokerto pada 22 Agustus 2020.

${ }^{20}$ Hasil wawancara dengan AA, narapidana Lapas Klas IIB Mojokerto pada 22 Agustus 2020.

${ }^{21}$ Hasil wawancara dengan B, narapidana Lapas Klas IIB Mojokerto pada 22 Agustus 2020.

${ }^{22}$ Hasil wawancara dengan F, narapidana lapas Klas IIB Mojokerto pada 22 Agustus 2020.
} 
vonis hingga berbulan-bulan, sehingga mempersulit mereka mengajukan Remisi dan hak-hak bersyarat lainnya; (3) Jarak waktu antara pengajuan PB dengan turunnya surat penetapanpemberian PB sangat lama, bahkan terdapat beberapa Narapidana yang hampir setahun belum juga mendapatkan penjelasan; (4) Adanya syarat tambahan bagi Narapidana tindak pidana khusus, yakni dalam Peraturan Pemerintah Nomor 99 Tahun 2012 yang mensyaratkan adanya justice collaborator bila ingin mengajukan Remisi dan PB; (5) ketidakpahamann para penegak hukum mengenai justice collaborator sehingga menghambat Lapas memberikan hak-hak bersyarat bagi Narapidana; (6) Tidak adanya koordinasi yang jelas antar instansi terkait penerapan justice collaborator.

Walaupun terdapat hambatan dalam penerapan hak-hak Narapidana, namun demikian penerapan hak-hak Narapidana masih mendapatkan dukungan baik dari narapidana itu sendiri maupun dari Lapas.Beberapa faktor pendukung terlaksananya penerapan hak-hak Narapidana yaitu: (1) Dukungan kerja sama Narapidana dalam mewujudkan keamanan dan ketertiban di lingkungan Lapas; (2) Dukungan para petugas Lapas yang membina Narapidana dengan tidakmenjadikannya sebagai obyek pembalasan, namun kepada pembinaan dari segi moralitas , spiritual dan kemandirian; (3) Dukungan dari petugas Lapas yang lebih bersifat pencegahan dalam menyikapi segala keadaan di Lapas, melalui pemberian pelayanan terbaik; (4) Dukungan petugas Lapas untuk selalu berkomunikasi baik dan berkoordinasi dengan penegak hukum lainnya dalam mendapatkan kejelasan permohonan justice colaborator narapidana; (5) Adanya ketentuan Surat Edaran Menteri Hukum dan HAM RI Nomor: M.HH13.PK.01.05.06 Tahun 2014 tentang Pelaksanaan Peraturan Pemerintah Nomor 99 Tahun 2012, ${ }^{23}$ yang menjadi solusi dalam penyelesaian terkait justice collaborator.

\footnotetext{
${ }^{23}$ Dalam Surat Edaran Menteri diatur bahwa apabila narapidana sebagai pemohon justice collaborator tidak mendapatkan balasan dari instansi penegak hukum dalam jangka waktu paling lama 12 (dua belas) hari kerja terhitung sejak tanggal surat permohonan dikirim, maka remisi dan atau pembeasan bersyarat tetap diberikan dengan ketentuan: Surat permohonan tidak ditanggapi selama 12 hari kerja maka dapat diteruskan prosesnya, dan pemberian remisi setelah narapidana yang bersangkutan menjalani paling sedikit 1/3 masa pidana, atau Surat permohonan ditanggapi dalam waktu 12 hari kerja dan disetujui, maka pemberian remisi setelah narapidana yang bersangkutan telah menjalani masa pidana lebih dari 6 bulan.
} 


\section{Implementasi Pembinaan di Dalam Lembaga Pemasyarakatan Khusus Anak} Klas I Blitar

Jaminan hak asasi manusia narapidana dalam pembinaan narapidana di lembaga pemasyarakatan yang telah di atur peraturan perundang-undangan yang berlaku, menurut penelitian yang dilakukan oleh Arini Zulfaida, pada tahun 2019 di lembaga pemasyarakatan khusus anak Klas I Blitar, belum dapat terimplementasikan sepenuhnya di langan, seperti: ${ }^{24}$

a. Kurangnya buku penunjang keagamaan;

b. Kurangnya kuantitas jumlah tenaga pengajar;

c. Terbatasnya jumlah ruang kelas dan buku pengetahuan.

Dari ketiga sebab tersebut maka peneliti berpendapat bahwa jaminan hak asasi manusia di lembaga pemasyarakatan LPKA Klas I Blitar belum sepenuhnya terimplementasikan dimana hal ini menciderai ketentuan Pasal 14 ayat (1) huruf c Undang-Undang Pemasyarakatan Nomor 12 Tahun 1995 dimana mendapatkan pendidikan dan pengajaran merupakan hak yang diterima oleh anak didik pemasyarakatan. Maupun jaminan hak asasi manusia narapisana dalam pembinaan narapidana di lembaga pemasyarakatan yang telah di atur peraturan perundangundangan yang berlaku, menurut penelitian yang dilakukan oleh Didik Endro Purwoleksono, Sarwirini, Maradona, pada tahun 2013 di lembaga pemasyarakatan anak Klas I Blitar, lembaga pemasyarakatan Klas I Tangerang belum dapat terimplementasikan sepenuhnya di lapangan, seperti: 25

a. Tujuan PembinaanBerdasarkan konsideran Undang-Undang Pemasyarakatan Nomor 12 Tahun 1995, tujuan pembinaan anak pidana yang dilakukan oleh LAPAS Anak Blitar adalah untuk mengubah watak, prilaku dan sikap para

\footnotetext{
${ }^{24}$ Arini Zulfaida, 'Pola Pembinaan anak didik pemasyarakatan sebagai upaya perbaikan moral di lembaga pemasyarakatan khusus anak klas I Blitar', (Repository Universitas Negeri Malang 2019) < http://repository.um.ac.id/52395> accessed 4 Agustus 2020.

${ }^{25}$ Laporan Akhir Penelitian Unggulan Perguruan Tinggi, Sarwirini, Didik Endro Purwoleksono, Maradona, 'Model Kebijakan Operasionalisasi Lembaga Pemasyarakatan Dalam Rangka Pembinaan Narapidana Yang Bersepektif Penghormatan Hak Asasi Manusia Narapidana (Studi di Lembaga Pemasyarakatan Anak Klas I Blitar dan Lembaga Pemasyarakatan Laki-laki Klas I Tangerang)' 2013.
} 
anak didik pemasyarakatan serta agar anak didik pemasyarakatan menyadari kesalahannya sehingga mereka sekeluar dari LAPAS Anak dapat diterima kembali oleh lingkungan masyarakat. Namun pada nyatanya belum tercapai sesuai dengan harapan. Karena seringkali terjadi bahwa seorang bekas anak didik pemasyaratan sekluar dari LAPAS Anak masyarakat tidak mau menerima kembali bekas anak didik pemasyarakatan tersebut dengan cara mengucilkan bekas anak pidana dari lingkungan masyarakat.

b. Kesenjangan Pola Pembinaan dengan Pola Pembalasan Ditinjau dari latar belakang kegiatan yang dilakukan di Lembaga Pemasyarakatan berdasarkan konsideran Undang-undang Nomor 12 Tahun 1995 pada prinsipnya kegiatan di lembaga Pemasyarakatan bukan sebagai sarana penjeraan atau pembalasan melainkan lebih kepada suatu proses pembinaan antara pihak LAPAS dengan pihak warga binaan pemasyarakatan. Hal ini juga diperjelas dalam Peraturan Pemerintah No. 31 Tahun 1999 bahwa kegiatan di dalam LAPAS merupakan pembinaan. Namun selain ditinjau dari ketentuan peraturan perundang-undangan yang ada, di dalam prakteknya di lingkungan masyarakat mengangap bahwa kegiatan di LAPAS Anak lebih ke arah pembalsan atau penjeraan.

c. Kualitas penyelenggaraan makanan

Pemberian makanan yang layak telah diatur dalam Peraturan Menteri Hukum dan Hak Asasi Manusia Republik Indonesia Nomor: M.HH-01.PK.07.02 Tahun 2009 Tentang Pedoman Penyelenggaraan Makanan Bagi Warga Binaan Pemasyarakatan di Lembaga Pemasyarakatan dan Rumah Tahanan Negara. Namun Pada prakteknya anak didik pemasyarakatan mendapatkan lauk garam saja sudah "Alhamdulillah", terlebih kualitas nasi yang diberikan juga berasal dari beras yang tidak baik mutunya.

Kurang terpenuhinya hak warga binaan pemasyarakatan akan perawatan dalam bentuk penyediaan makanan yang layak akan berdampak dengan ketidakpuasan warga binaan akan kebutuhn dasarnya, sehingga mereka mencari alternatif lain untuk memenuhi kebutuhannya tersebut. 


\section{Analisis Penerapan Hak-hak Narapidana dalam Persepektif HAM}

Sistem pemidanaan dengan berorientasikan pada pembinaan dapat didasari dengan adanya pemikiran dari Dr. Saharjo yang menyatakan bahwa "Narapidana merupakan seseorang yang mengalami keretakan hubungan hidup, kehidupan dan penghidupanya."Apabila seorang Narapidana diberikan sanksi pidana penjara dan penghukuman pembalasan, maka belum tentu dari diri Narapidana itu sendiri memiliki kesadaran atas kesalahan yang telah diperbuatnya. Oleh karena itu, perlu Narapidana mengubah dirinya sendiri melalui kesadarannya yang ia dapatkan dari hasil pembinaan di Lapas.

Hak-hak bersyarat ialah hak-hak yang sangat menjadi perhatian bagi Narapidana. Banyak Narapidana berharap atas hak-hak bersyarat tersebut sehingga mereka berupaya untuk berperilaku baik di Lapas. Namun bagi beberapa Narapidana yang mengalami kesulitan menerima Remisi, mereka terlihat apatis. Mereka menyatakan bahwa tidak perlu memperbaiki diri di Lapas bila mereka tidak mendapatkan hak mereka.Tentunya sikap dan pernyataan beberapa Narapidana tersebut memberikan gambaran kecenderungan adanya sikap pamrih atau tidak adanya kesadaran dari mereka untuk memperbaiki diri, dan ini dapat dikatakan sebagai sikap manusia pada umumnya.

Hak-hak bersyarat juga menjadi perhatian bagi Lapas karena ketika diperolehnya hak Remisi atau PB, maka akan mengurangi jumlah penghuni di Lapas. Namun dalam penerapanya di lapangan, upaya penerapan hak-hak bersyarat mengalami beberapa kendala, baik karena faktor internal dari Narapidana sendiri, faktor luar diri Narapidana, maupun faktor dari kebijakan intansi lain di luar Lapas. Kendala dalam penerapan HAM bagi Narapidana tidak dapat dibiarkan mengingat bila terjadi abuse of power atau pembiaran/kelalaian (omission), bahkan atas tindakan sengaja (comission) dari aparat penegak hukum, maka akan memunculkan opini adanya pelanggaran HAM. Hal ini tidak semestinya terjadi mengingat Pemerintah Indonesia memiliki komitmen menghormati HAM dengan merativikasiperaturan HAM internasional seperti ICCPR dan ICESCR serta telah melakukan internalisasi nilai-nilai tersebut ke dalam sistem peraturan perundang-undangan nasional. 
Terkait dengan PP No. 99 Tahun 2012 yang mensyaratkan adanya justice collaborator yang ditujukan hanya bagi Narapidana tindak pidana khusus dapat uraikan sebagai berikut; walaupun secara hierarki undang-undang telah menentukan adanya hak-hak bagi Narapidana untuk memperoleh keringanan masa pidana, namun ketika adanya Peraturan Pemerintah No. 99 Tahun 2012 memberikan hambatan dalam penerapan hakhak Narapidana khususnya hak-hak bersyaratnya. Hal ini sedikit menyimpang dari Pasal 7 ayat (1) UndangUndang No. 12 Tahun 2011 yang mengatur mengenai Jenis dan Hierarki Peraturan Perundang-undangan yang berlaku di Indonesia adalah:

1. UUD 1945;

2. TAP MPR;

3. Undang-Undang atau Peraturan Pemerintah Pengganti Undang-Undang (PERPU);

4. Peraturan Pemerintah;

5. Peraturan Presiden;

6. Peraturan Daerah Provinsi;

7. Peraturan Daerah Kabupaten/Kota.

Tata urutan perundang-undangan yang telah dipaparkan diurutkan dari atas ke bawah secara hierarki, dimana peraturan dibawahnya tidak boleh bertentangan atau mengatur hal selain yang diperintahkan oleh peraturan diatasnya.Hal ini sesuai dengan salah satu asas hukum, yakni peraturan yang lebih rendah kedudukannya tidak boleh bertentangan dengan peraturan yang lebih tinggi. Dengan cara seperti itu dimaksudkan akan adanya tertib administrasi pengaturan perundang-undangan yang lebih baik dan tertata dan untuk menghindari adanya pelampauan wewenang maupun timpang tindih kewenangan.

Mengenai Surat Edaran Menteri Hukum dan HAM RI Nomor: M.HH-13. PK.01.05.06 Tahun 2014 tentang Pelaksanaan Peraturan Pemerintah No. 99 Tahun 2012 tersebut dapat dikatakan sebagai solusi dalam menyelesaikan masalah yang dihadapi Narapidana khususnya dan Lapas pada umumnya. Namun Surat Edaran Menteri masih belum dapat menjawab permasalahan yang semestinya karena dalam praktiknya ditemukan bahwa masih banyak aparat penegak hukum, seperti Kepolisian, Kejaksaan dan Pengadilan serta Lapas, yang memiliki interpretasi 
berbeda-beda terhadap justice collaborator. Perbedaan perspesi ini yang kemudian memantik adanya "saling lempar" tanggung jawab antar instansi dalam pemberian persetujuan justice collaborator.

Perlu dicermati bahwa terjadinya perbedaan persepsi atau interpretasi pada instansi di luar Lapas atas pemahaman Pasal 1 UU Pemasyarakatan menjelaskan bahwa "pemasyarakatan merupakan kegiatan untuk melakukan pembinaan Warga Binaan Pemasyarakatan berdasarkan sistem, kelembagaan, dan cara pembinaan yang merupakan bagian akhir dari sistem pemidanaan dalam tata peradilan." Dengan demikian ketika seseorang telah divonis pidana dan telah masuk ke dalam Lapas sebagai warga binaan, maka ia menjadi Narapidana yang telah melewati semua proses dari sistem pemidanaan dalam tata peradilan sehingga tidak diperlukan kembali adanya ketentuan atau syarat bila ia ingin mengajukan remisi dan/atau pembebasan bersyarat sebagai bentuk hukuman tambahan.

\section{Kesimpulan}

Pengaturan tentang sistem pemasyarakatan sebagai bagian dari integrated criminal justice system sudah cukup mengatur tentang pembinaan narapidana didalam lembaga pemasyarakatan bersepektif penghormatan hak asasi manusia narapidana yang telah diatur dalam UU Pemasyarakatan, dan peraturan pelaksanaan

Impelementasi hak asasi manusia narapidana dalam pembinaan narapidana lembaga pemasyarakatan yang dijamin Undang-Undang belum sepenuhnya dipenuhi oleh pemerintah dalam hal ini Dirjen Pemasyarakatan Kementrian Hukum dan Hak Asasi Manusia. Daya tampung LP yang tidak sesuai dengan jumlah narapidana penghuni LP menjadi masalah umum yang berakibat pada kurangnya pemenuhan kebutuhan pokok minimal narapidana seperti makan minum dan fasilitas lain. Kondisi tersebut disebabkan kurangnya anggaran dalam pengelolaan LP dan belum cukup profesionalnya petugas LP dalam aspek pembinaan fisik maupun mental warga binaan pemasyarakatannya.Faktor penghambat dalam penerapan hakhak Narapidana antara lain (1) relatif bersifat monoton yang terjadi sejak lama tentang tentang kelebihan narapidana, keterbatasan anggaran, lemahnya koordinasi antar 
instansi (2) maupun bersifat teknis dan administratif dokumen yang harus dimiliki Narapidana untuk dapat memperoleh hak-haknya, (3) dinamika hukum dalam perlakuan terhadap Narapidana.

\section{Daftar Bacaan}

\section{Buku}

Andi Hamzah, Sistem Pidana dan Pemidanaan di Indonesia, (Pradnya Paramita 1993).

Djoko Prakoso, Nurwachid, Pidana Mati Di Indonesia Ini, (Ghalia Indonesia 1984).

Harsono, Sistem Baru Pembinaan Narapidana, (Djambatan 1995).

Muladi, Hak Asasi Manusia : Hakekat, konsep dan Impelementasinya Dalam Persepektif Hukum Dan Masyarakat, (Refika Aditama 2005).

Muladi dan Barda Nawawi Arief, Teori-teori dan Kebijakan Hukum Pidana, (Alumni 1999).

NN, 40 Tahun Pemasyarakatan Mengukir Citra Profesionalisme. (Direktorat Jendral Pemasyarakatan Departemen Kehakiman dan Hak Asasi Manusi Republik Indonesia 2004).

Peter Bachr, dkk., (ed), Instrumen Internasional Pokok-pokok Hak Asasi Manusia, (Yayasan Obor Indonesia 1997).

Peter Mahmud Marzuki, Penelitian HukumEdisi Revisi, (Pernada Media 2017).

Rhona Smith K.M., ,et al., Hukum Hak Asasi Manusia, Cetakan Pertama, (Pusat Studi Hak Asasi Manusia Universitas Islam Indonesia 2008).

Romli Atmasasmita, Dari Pemendjaraan ke Pembinaan Narapidana, Alumni 1971).

Schwartz, D.Richard, On Legal Sanction (Tentang Hal Sanksi Hukum), diringkas ke dalam bahasa Indonesia oleh Soetandyo Wingnyo Soebroto, dalam Peran Kriminologi Dalam Hukum Pidana,( Universitas Airlangga, Fakultas Hukum 1976).

Soerjono Soekanto dan Sri Mamudji, Penelitian Hukum Normatif,Cetakan ke-8, (Raja Grafindo Persada 2004). 


\section{Jurnal, Karya Tulis, Laporan Akhir Penelitian}

Andhika Saputra, "Impelementasi Hak Asasi Manusia Dalam Pelaksanaan Pembinaan DI Lembaga Pemasyarakatan Kelas IIB Cianjur", Karya Tulis Akhir, 2012

E.Z. Leasa, 'Penerapan Sanksi Pidana dan Sanksi Tindakan Dalam Kebijakan Legislasi’ (2010) 16 Jurnal Sasi.

Indiyah, 'Gangguan Psikologis pada Narapidana Kasus Narkoba,(2001) Hasil Penelitian Universitas Wangsa Manggala.

S. Latifa, "Perubahan Kepribadian Narapidana Sesudah Menerima Pembinaan di Lembaga Pemasyarakatan”, (1994) Skripsi Fakultas Psikologi Universitas Gadjah Mada.

Sarwirini,DidikEndroPurwoleksono, Maradona, 'ModelKebijakanOperasionalisasi Lembaga Pemasyarakatan Dalam Rangka Pembinaan Narapidana Yang Bersepektif Penghormatan Hak Asasi Manusia Narapidana (Studi di Lembaga Pemasyarakatan Anak Klas I Blitar dan Lembaga Pemasyarakatan Laki-laki Klas I Tangerang)' (2013) Laporan Akhir Penelitian Unggulan Perguruan Tinggi.

Simeon Tonggengbio, 'Sistem Pemidanaan Dalam Penjatuhan Pidana Penjara Berdasrkan Undang-Undang Nomor 12 Tahun 1995 Tentang Pemasyarakatan,' (2016) IV Lex Administratum.

Thomas Sunaryo, 'Diktat/Materi Kuliah Sistem Pemasyarakatan Indonesia' (2001) Penologi.

\section{Laman}

Mahfud M.D, 'Definisi Hak Asasi Manusia', <http://organisasi.org/pengertian macam_dan_jenis_hak_asasi_manusia_ham_yang_berlaku_umum_global_ pelajaran_ilmu_ppkn_pmp_indonesia> diakses tanggal 29 Mei 2020.

Poerwadarminta, 'Kamus Besar Bahasa Indonesia : Pembinaan'. $<$ http://kamus Besar_Bahasa_Indonesia_Pusat_Bahasa> diakses pada 29 mei 2020.

Atmasasmita, Romli, 'Remisi adalah hak bukan hadiah, pencitraan', $<$ http:// nasional.sindonews.com/read/2013/07/31/18/767478/remisi-hak-bukanhadiah-bukan-pencitraan> diakses pada 1 juni 2020 . 
Fajar Putra: Jaminan Hak Asasi...

--halaman ini sengaja dibiarkan kosong-- 